\title{
TRADITION AND THEOLOGY IN LUKE
}

\author{
(LUKE 8:5-I5) \\ By I. HOWARD MARSHALL
}

The purpose of the present paper is to make a small contribution towards discovering to what extent the distinctive theological motifs of the Gospel of Luke are due to the author himself or to the various sources and traditions which he employed.*

In the present phase of Gospel study great stress is being placed upon the part played by the Evangelists themselves in shaping the tradition which they inherited and even in adding their own contribution to it. The result is a tendency to label whatever is distinctive in a particular Gospel as the contribution of the Evangelist himself. An important principle of method is being stated here. In any attempt to work back from the finished Gospels to the earlier stages of tradition which lie behind them, the first layer to be skimmed off will be that which historically came last, namely the work of the final editors or authors. It is right, therefore, that scholars should concentrate their attention on this aspect of Gospel study.

Nevertheless, there is a distinct danger that in the first flush of enthusiasm for a new method the scholar may be overzealous in discovering the hand of the Evangelist and play down the importance of the Gospel tradition which he inherited. The scholarship of an earlier generation perhaps went to the other extreme. One thinks, for example, of Vincent Taylor's study Behind the Third Gospel (1926) which argued strongly for the existence of an earlier Gospel, Proto-Luke, incorporated in the present Gospel of Luke, and attempted to delineate the characteristic theology of that hypothetical document. Taylor had no difficulty in sketching an outline of Proto-Lucan

* Given at the New Testament Study Group of the Tyndale Fellowship at Cambridge, July 1968. 
theology; he argued that it was consonant with the theology of Luke himself as seen in the birth stories and in Acts, and that it had a primitive character in keeping with its date. Essentially, therefore, the theology of Luke was identified with that of the sources used in Proto-Luke. A modern critic would no doubt urge that Taylor made little attempt to discriminate between the theology of the sources employed in Proto-Luke and that of Luke himself, an argument to which I think Taylor would have replied that the primitive character of Proto-Lucan theology was a guarantee that it came from the early traditions of the church and was not a late creation by Luke himself.

If, however, one may try to fault Taylor for not attempting to make this discrimination, it is not at all certain that the modern method of approach is more firmly founded. A recent paper by C. H. Talbert raises considerable misgivings in this respect. ${ }^{1}$ Talbert poses the methodological question: 'How can one be sure that the total impression one receives from the Lucan story of Jesus is really a reflexion of the Lucan mind ?'2 He answers: 'The scholar knows Luke's sources. He has them before him. By a careful comparison of Luke-Acts with its sources one can determine how Luke used his material, what tendencies are present in this usage, and thereby infer something of the Lucan mind . . . The method comes clear if we ask: if Luke had given us just the picture of Jesus that could have been derived from his available models (Mark, $Q$, and the early kerygma reflected in some of the speeches in Acts), how would this compare with the picture we get in his finished product? Such a question brings the reader of the Gospel to an awareness that the entire framework of the Lucan picture of Christ would be missing if the Evangelist had merely copied his models. Missing would be the birth narratives (Luke i-ii), the narrative of the ascension of Jesus (Acts $i$ ), the lengthy journey of Jesus to Jerusalem (Luke ix. 5 Iff.), and the distinctive way in which the beginning of the public ministry of Jesus is depicted (Luke iii-iv). The overall structure of Luke's picture of Jesus, therefore, is due to his deviation from his available models.' 3

1 G. H. Talbert, 'An Anti-Gnostic Tendency in Lucan Christology', NTS 14 (1967-68) 259-27I.

2 Ibid., 260.

3 Ibid., 260 . 
We are not concerned here with the correctness or otherwise of the conclusions which Talbert reaches by the use of this method in the main body of his essay. For our present purpose it is enough to note that his statement of method is marred by a number of faults. On the one hand, Talbert professes to have a clearer knowledge of Luke's sources than is actually the case. In the event we only have Mark available for inspection, very probably in the form in which it was used by Luke as a source. ${ }^{4}$ We do not possess $Q$, and attempts to lay bare the original form and content of this putative source are rendered extremely difficult since, if Luke has exercised his editorial talents upon it, Matthew must equally be presumed to have done the same. Nor, finally, do we possess the third source named by Talbert, 'the early kerygma reflected in some of the speeches in Acts'; all that we possess is the early kerygma reflected in the Epistles (and therefore also subject to editorial modification), and it is not certain that this latter material, once it has been pieced together from its redactional settings, is necessarily the kerygma of the early church rather than the deposit of several kerygmas. On this score, therefore, Talbert is over-optimistic, and he has under-emphasized the difficulty of comparing Luke's product with his materials.

But, on the other hand, Talbert has failed to reckon with other 'available models' which may have been employed by Luke. Although he refers in passing to 'the existence of certain traditions peculiar to Luke commonly designated $L^{\prime},{ }^{5}$ it is remarkable that he does not mention $\mathrm{L}$ in his list of sources. ${ }^{6}$ It is at least arguable that much of Luke's characteristic material is due to the influences of such models rather than to his own mind; in other words, the decisive influence in shaping Luke's mind may have been $L$ rather than the theological ideas current in Luke's environment. But if this principle is admitted, it becomes open to question whether the birth stories, the ascension narrative, the journey to Jerusalem and the be-

4 It will be assumed in this article that Luke used Mark as a source. Nevertheless, the phenomenon commonly known as 'the minor agreements of Matthew and Luke against Mark' strongly suggests that some other factor than mere use of Mark as we know it must be adduced to solve this part of the Synoptic Problem.

5 Ibid., 260 n. 5.

- In fairness to Talbert it should be observed that he has presumably not mentioned $L$ in this list because (unlike Mark, $Q$ and the kerygma in Acts-on Talbert's view of them) its contents cannot be confirmed independently. 
ginning of the public ministry in Luke are all deviations from the Evangelist's models. They may well be due to models that have not been independently preserved for us, and indeed there are good grounds for this supposition.?

We wish to argue, therefore, that Luke's theology may be the theology of his sources to a much greater extent than is often allowed. Here we may quote in favour of this view some wise words of A. R. G. Leaney. They occur in the course of his defence of the originality of the clause, 'May Thy Holy Spirit come upon us and cleanse us' in the Lord's Prayer, but the general point which is made here is quite independent of the validity of this particular example. Leaney argues that on the basis of this text of Luke $\mathrm{I}$ I:2, '... it would follow that the Lord's Prayer was one of the influences which formed Luke's conception of the Holy Spirit rather than that his form of the Lord's Prayer has been formed by that conception. This is quite possible: to argue that "Lucan theology" accounts for the presence of a certain passage, the use of a particular vocabulary, or a characteristic way of presenting an incident, is not to preclude the influence of a source or sources. Liturgy may well have provided Luke with the canticles of the first two chapters, but they are full of "Lucan theology"; it is indeed to much of the non-Marcan material, perhaps to a definable strand in it, that much of his understanding of the gospel is owed. Lucan theology may often be the theology of his sources.'8

Our difficulty arises when we try to discriminate between Luke's sources and the redaction which they may have undergone at the hand of the Evangelist. How can one differentiate between $\mathrm{L}$ in its original form and its redacted form in Luke? It seems to me that at this point the method advocated by Talbert and by other recent scholars ${ }^{9}$ can be adopted and freed from some of its uncertainties. It is possible to make a reasonably objective study of how Luke has used Mark because we

7 The Hebrew background of the birth stories indicates that a source is being used. The narrative of the ascension is probably from Luke's special source for the passion and resurrection. The journey motif is found in Mark and is historical (T. W. Manson, The Servant-Messiah, Cambridge University Press (r953) 75-79). On Luke 3-4 see H. Schürmann, 'Der "Bericht vom Anfang"', TU 87 (1964) 242-258.

${ }^{8} \mathrm{R}$. Leaney, 'The Lucan Text of the Lord's Prayer (Lk. I I:2-4)', NovT I (1956) 105f. (103-11 I).

${ }_{9}$ H. Conzelmann, Die Mitte der Zeit, J. G. B. Mohr, Tübingen (1964 ${ }^{5}$ 7f.; J. Rohde, Die Redaktionsgeschichtliche Methode, Furche Verlag, Hamburg (1966) 29 . 
have Mark available for comparison. Once we have derived certain principles of procedure from this comparison and seen how Luke goes to work, we can then go on to examine the areas of his Gospel where he uses other sources and see if the same procedures are visible. Thus a study of Luke's use of Mark gives us a limited objective basis for examining Luke's use of $Q$ and $\mathbf{L}$ and imposes a restraint upon ill-based, subjective criticism. We are in effect using Luke's use of Mark as a 'control' in our attempts to discover how Luke has used his other sources.

The method proposed is of course not altogether free from risk and uncertainty.

I. It assumes that Luke has treated all his sources in very much the same manner, so that the analogy of his use of Mark can be legitimately applied to his use of other sources. One strong argument in favour of this assumption is that Luke has imposed a remarkable unity of style upon his whole composition. Thus in Acts, where we have no extant sources available for comparison, it is notoriously difficult, if not impossible, to isolate sources on stylistic grounds. It is probable that if Luke has revised the style of all his sources to produce a uniform impression the same will also be true at the conceptual and theological level.

2. Another risk is that Luke's revision of Mark may have been carried out in order to conform it to the pattern of his other main source or sources; what, therefore, we tentatively identify as Lucan redaction in his Marcan sections may not necessarily, therefore, be stamped as Lucan when it reappears in non-Marcan sections; it may be drawn from tradition. In theory a check on this point might be obtained by noting places where a suspected Lucan motif is absent from the Matthaean version of a $Q$ passage.

3. A third factor is that oral traditions may well have continued in the church and influenced the redaction of the written sources, including Mark. Such traditions may have been isolated and fragmentary, and their use spasmodic. We must beware of attempting to force every piece of editorial activity into a preconceived pattern.

Despite these uncertainties the method proposed seems a feasible one, and we can now proceed to make an experiment in applying it. First of all, however, we must make some general 
remarks about Luke's use of Mark before looking at some particular examples.

In general, Luke has subjected Mark to such a thorough stylistic revision that if we did not have Mark itself available for comparison it would be impossible for us to reconstruct it in detail. There is no need for us to comment at length on Luke's revision of Mark's language and style; the matter has been discussed very fully in a number of studies. ${ }^{10}$ Two points only need be noted. First, Lucan revision is much more thorough in the introductions and conclusions of the various pericopes than in their middle sections. See, for example, Luke 5:I2-I6 (=Mk. I:40-45); 6:6-I I (=Mk. 3:I-6); and 20:20-26 (=Mk. I2:13-17). Second, partly as a consequence of the previous point, the words of Jesus and of other speakers are much less subject to alteration than the narrative material. See, for example, Luke 9:22-27 (=Mk. 8:3I-9:I) and Luke 7:24-35 (=Mt. I I:7-r9).11

A special problem is raised by Luke's omission of certain sections from Mark. There are two omissions of considerable extent (Mk. 6:45-8:26; and 9:42-10:12), but it is probable that these sections of Mark were thought to be repetitive and that their content was covered by other material, rather than that there was any theological objection to them. More important is the problem of sections of Mark which are omitted and replaced by similar sections at different points in the Gospel. It is a nice question whether in these cases Luke is expressing a preference for his other sources or giving us what amounts to a thorough transformation of the Marcan material. If the latter were the case, we should have some particularly striking evidence for Lucan modification of Mark. Such indeed is the view

10 A. Plummer, The Gospel according to S. Luke, T. \& T. Clark, Edinburgh (1901 ${ }^{4}$ ) xli-1xvii; J. C. Hawkins, Horae Synopticae, Clarendon Press, Oxford (19092); H. J. Cadbury, The Style and Literary Method of Luke, Harvard Theological Studies, Cambridge, Mass. (1920); B. S. Easton, The Gospel according to St Luke, T. \& T. Clark, Edinburgh (1926); H. F. D. Sparks, "The Partiality of Luke for "Three", and its Bearing on the Original of $Q^{\prime}, \mathcal{F} T S 37$ (1936) $141-145 ; R$. Morgenthaler, Die lukanische Geschichtsschreibung als Zeugnis, Zwingli-Verlag, Zürich (1948); H. Schürmann, Der Paschamahlbericht, Aschendorffsche Verlagsbuchhandlung, Münster (1953-r 957). For full bibliography see the last-named work.

11 'In the narrative material, above all in the introductions to the pericopes, we encounter the Lukan linguistic peculiarities four times as often as in the Jesussayings, and correspondingly the number of words which agree with Mark in the Jesus-sayings exceeds those in the narrative sections' (W. G. Kümmel, Introduction to the New Testament, SCM Press, London (1966) 97). 
which Conzelmann appears to favour, although in the case of Luke 4:16-30 and 5:I-I I he admits the impossibility of proving it. ${ }^{12}$ In fact, however, the former view is much more likely. For, firstly, in cases where Mark and Q overlap, it is fairly clear that while Matthew has conflated the two sources, Luke has usually followed $Q$ exclusively, making little or no use of Mark. ${ }^{13}$ Thus, in those texts where we have a criterion for discovering whether Luke has used Mark and/or another source, the use of another source instead of Mark is most probable. It may be assumed that the same is true in the texts which have no parallel in Matthew. Secondly, the amount of alteration in the text of Mark required to produce the so-called transformations is so great in comparison with Luke's normal treatment of Mark that it is unlikely to have taken place. Why, we may ask, was Luke so surprisingly conservative in his treatment of most of Mark and so radical in these few cases? Thirdly, the sections in question usually occur in a different place in the structure of the Gospel from their position in Mark. Where, however, Luke is clearly following Mark, variations in order are extremely rare and can be easily accounted for in terms of literary technique. It is, therefore, in my opinion highly unlikely that such passages as Luke $4: 16-30 ; 5: 1-11 ; 7: 36-50$ and ro:25-28 are free renderings of the corresponding passages in Mark, and they should not be used as sources for evidence for Luke's use of Mark.

After these rather lengthy preliminary remarks we now consider in more detail Luke's treatment of Mark. We have selected for consideration the parable of the sower and its interpretation (Mk. 4:3-9, I 3-20 = Lk. 8:5-8, II-I5). The passage is of special value for our purpose because of its theological content and also because it has recently been the subject of a detailed essay by J. Dupont. ${ }^{14}$

Luke's version of the parable itself is about three-quarters

${ }^{12} \mathrm{H}$. Conzelmann, op. cit., 26.

13 E.g. Lk. I 3:18-2I parr.; I I:14-23 parr. (For the view that here Luke used Matthew see R. T. Simpson, 'The Major Agreements of Matthew and Luke against Mark', NTS 12 (1965-66) 273-284.)

${ }_{14} \mathrm{~J}$. Dupont, 'La parabole du semeur dans la version du Luc', in W. Eltester and F. H. Kettler (ed.), Apophoreta (Festschrift für Ernst Haenchen), Verlag Alfred Topelmann, Berlin (1964) 97-108. See also W. G. Robinson, Jr., 'On Preaching the Word of God (Luke 8:4-2I)', in L. E. Keck and J. L. Martyn (ed.), Studies in Luke-Acts, Abingdon Press, Nashville (1966) 131-138. 
of the length of Mark's, and after the introduction it falls into four neat pairs of lines. Apart from the changes produced by this abbreviation and stylistic revision, Luke has altered the

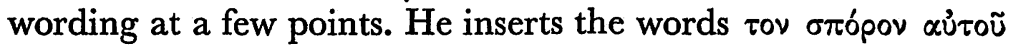
in verse 5 ; he tells us that the seed which fell by the path was trodden down $\left(\varkappa \alpha \tau \varepsilon \pi \alpha \tau^{\prime} \theta \eta \eta\right)$, and he observes that the seed on the rock withered because it had no moisture (ix $\mu \alpha \delta \delta \alpha$;

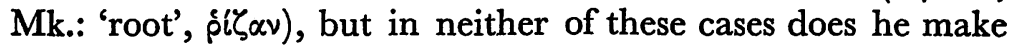
use of the detail in the interpretation. He adds the verbs $\varphi v \omega$

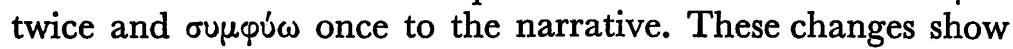
that Luke or oral tradition felt quite free to modify details in the wording of the story, something which modern preachers regularly do when they are recounting the parables. ${ }^{15}$

It is in the interpretation of the parable that the alterations are significant. Luke repeats the word 'seed' and identifies it with 'the word of God', whereas Mark simply says that 'the sower sows the word'. He twice inserts the verb $\pi \iota \sigma \tau \varepsilon^{\prime} \omega$ to indicate the response that is made or ought to be made by those who receive the word (verses 12 and I 3 ), he expresses the result of receiving the word and believing it by the verb $\sigma \omega \zeta \omega$, and he uses the word $x \alpha p \delta i \alpha$ twice (once in common with Mt. I3:I9) to indicate the lodging place of the word. For Mark's $\theta \lambda i \psi$ i 5

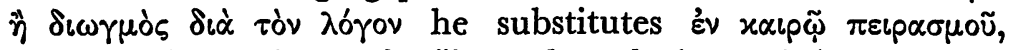

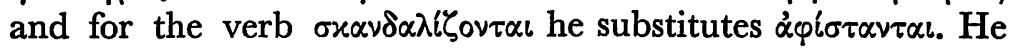
alters the list of temptations corresponding to the thorns in the parable from Mark's 'the cares of the world, and the delight in riches, and the desire for other things' to 'the cares and riches and pleasures of life'. Finally, he draws out the analogy of the good soil by speaking of 'an honest and good heart' (Ev reapdia. $\varkappa \alpha \lambda \tilde{n}$ x $\alpha \dot{i} \alpha \gamma \alpha \theta \tilde{n})$, and he states that the people possessed of

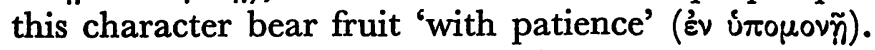

Let us consider these changes in turn.

I. According to Dupont the parable of the sower has become in Luke a parable of the seed. The sower is not mentioned in the interpretation, and the seed is identified with the word of God. ${ }^{16}$ This is an exaggeration. In Mark the sower plays no

\footnotetext{
${ }^{15}$ It may be observed in passing that none of Luke's alterations in the parable show any point of contact with the version in the Gospel of Thomas 9. W. G. Robinson, op. cit., notes that Luke's interpretation is based upon Mark's interpretation and not upon his own revised form of the parable.

16 Ibid., 97.
} 
essential part in the parable or the interpretation, and throughout the interpretation the sowing of the seed is described in the passive voice. The parable is already a parable about the seed rather than the sower in Mark, and Luke's introduction of the word $\sigma \pi$ ópos simply brings out, as is often the case, what is already implicit in Mark.

As for stress on the word, so far as mere statistics are concerned, Mark uses $\lambda$ boros eight times in the passage against only four times in Luke. What is new is the qualification of

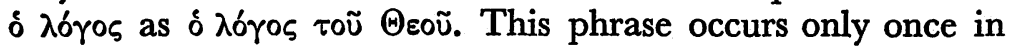
Mark (7:13) where it refers to the Old Testament ( $c f$. Jn. 10:35). Mark can speak of the message of Jesus as 'the word' ( $2: 2 ; 4: 33$; $c f$. 8:32). Luke, however, describes the teaching of Jesus as 'the word of God' in 5:I, a verse at the beginning of a pericope in which we may perhaps expect to find the hand of Luke. Thus the teaching of Jesus is declared to be the word of God in the same way as the Old Testament or, as frequently in Acts and the rest of the New Testament, the apostolic preaching is the word of God. It is this 'high' estimate of the teaching of Jesus which is notable in Luke. We find it again in 8:2 I where Mark's phrase 'do the will of God' (Mk. 3:35) is replaced by 'hear and do the word of God'. Commentators suggest that Luke is making a clear link with the parable of the sower, especially since in his Gospel the incident of Jesus' real kindred follows the parabolic teaching instead of, as in Mark, preceding it. ${ }^{17}$ There then arises the problem of $11: 28$. In this brief pericope peculiar to Luke concerning the woman who pronounced a blessing on Jesus' mother comes the saying 'blessed are those who hear the word of God and keep it'. This brief pronouncement story is very similar in its basic point to the incident of Jesus' true kindred, ${ }^{18}$ and furthermore it appears to follow the $Q$ version of the Beelzebub controversy just as Mark's story follows his account of the same debate. The question arises whether, just as Luke has replaced 'the will of God' by 'the word of God' in 8:2 I, he has formed 'hearing and doing the word of God' in I I:28 out of an original reference to hearing and doing 'the will of God' ( $c f$. Lk. I2:47; 22:42; Mt. 6:10;

17 E. Klostermann, Das Lukas-Evangelium, J. C. B. Mohr, Tübingen (19292) 99; B. S. Easton, op. cit., II 7 .

${ }_{18}$ R. Bultmann, Die Geschichte der synoptischen Tradition, Vandenhoeck \& Ruprecht, Göttingen (1958 ${ }^{4}$ ) 29 . 
7:2I ; $21: 31$ ) or 'my words' (cf. Lk. 6:47-49 = Mt. 7:24-27). This possibility is raised by G. Kittel and demands consideration. ${ }^{19}$ On the other hand, it seems certain that Matthew 7:2 I which speaks of 'doing the will of my Father in heaven' is secondary to Luke 6:46 which has 'doing what I say' ${ }^{20}$ Jesus thus spoke in terms of great authority regarding His own words, and, if Luke has described His teaching as 'the Word of God', he is developing Jesus' own point of view ( $c f . \mathrm{Jn}$. I 7:14).

2. The second point to be discussed is the use of $\pi \iota \sigma \tau \varepsilon \dot{v} \omega$ in verses 12 and I3. The verb itself is used somewhat sparsely by Luke, only nine times (including the present two instances) compared with its ten occurrences in Mark. Once the verb means 'to entrust' (Lk. I6:I I), three times it is used of believing angelic messages or the Old Testament prophecies (Lk. $\mathrm{r}: 20,45 ; 24: 25)$, and twice it is taken over from Mark (8:50= Mk. $5: 36 ; 20: 5=$ Mk. II:3I). It also occurs in $22: 67$, where Jesus says that His hearers will not believe any confession which He makes to them, a passage which may not be based on Mark, and finally in the present passage. On the other hand, Luke omits eight of Mark's uses of the word for various reasons.

The case is slightly different with the noun $\pi i \sigma \tau \iota s$ which Luke has eleven times in contrast with five times in Mark. Four of its occurrences in Luke are taken over from Mark (Lk. 5:20=Mk. 2:5; Lk. 8:25=Mk. 4:40; Lk. 8:48=Mk. $5: 34 ; \mathrm{Lk}$. I8:42=Mk. 10:52). The one other use of the term in Mark ( $11: 22)$ is paralleled by Luke $17: 6$ which is from a $Q$ section (=Mt. I 7:20). One other occurrence comes from $Q$ (Lk. $7: 9=$ Mt. 8:10). In two places the formula $\dot{\eta} \pi i \sigma \tau \iota s$ бou

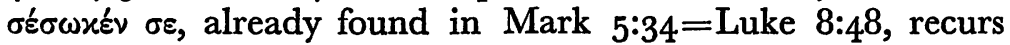
(Lk. 7:50; I 7:19); we shall return to these in connection with the use of $\sigma \omega \zeta \omega$. There remain two cases in Luke's special material, r8:8 and 22:32; the question arises whether there is reason to suppose that, as in 8:12f., Luke has added the reference to faith to his source. In the case of $18: 8$, 'When the Son of man comes, will he find faith on earth?', there are strong reasons for holding the saying to be pre-Lucan, and, in our

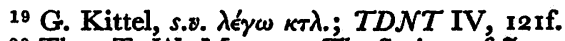
176.

20 Thus T. W. Manson, The Sayings of Jesus, SCM Press, London (1954') 6o,
}

C 
opinion, authentic teaching of Jesus; ${ }^{21}$ since the reference to faith is integral to the saying, we can be sure that this is not a case of Lucan reformulation. With 22:32, 'I have prayed for you that your faith may not fail', the problem is more complicated. In his extremely thorough analysis of the pericope, Schürmann comes to the conclusion that the whole saying stems from a pre-Lucan tradition which has been revised by Luke; he concedes that the phrase $\dot{\eta} \pi i \sigma \tau l \varsigma$ бou may possibly be due to Lucan redaction. His argument is that whereas in the Synoptic material generally the emphasis is on the element of trust ('das Vertrauensmoment'), here and in I8:8 we find the same concept of faith ('Glaubensbegriff') as in Acts 6:5, 7 ; I1:24; I3:8; I4:22; $15: 9$ and $16: 5$ and frequently in the Epistles. ${ }^{22}$ This is not a compelling argument. We have just seen that $18: 8$ is thoroughly acceptable as a saying of Jesus, and the concept of faith as an attitude of continuous trust is perfectly in line with the stress elsewhere in the Gospels on the initial moment of faith. Moreover, the usage cited from Acts is not a unified one; 'faith' here may mean a subjective attitude (as in Acts 6:5) or the objective content of Christianity (as in Acts 6:7). The concept of faith in Luke 22:32 fits in best with the idea expressed in Luke 18:8 ( $c f$. Acts 14:22; 16:5), and there seems to be no good reason to claim that it is especially Lucan. Our attempt, therefore, to discover a distinctive Lucan use of $\pi \iota \sigma \tau \varepsilon \dot{\omega} \omega$ and $\pi i \sigma \tau \iota \varsigma$ on the basis of 8:12f. is unfruitful. The most that can be said is that in linking $\pi\llcorner\sigma \tau \varepsilon \dot{v} \omega$ with the words of Jesus Luke is using a terminology that is not otherwise found in the Synoptic Gospels to express what Jesus meant by 'hearing and doing his words'; the nearest approach to it is perhaps Mark 1:15, 'repent and believe in the gospel', a saying which we see no reason to regard as inauthentic.

3. The third key word to be examined is $\sigma \omega \dot{\zeta} \omega$. It is used seventeen times by Luke, compared with fourteen times in Mark. In ten cases Luke has taken it over from Mark (Lk. 6:9= Mk. $3: 4$; Lk. 8:48=Mk. 5:34; Lk. 8:50 is perhaps based on Mk. 5:23 (cf. 5:28); Lk. 9:24 (bis) =Mk. 8:35 (bis); Lk. 18:26=Mk.

${ }^{21} \mathrm{~J}$. Jeremias, The Parables of Fesus, SCM Press, London (1963 ${ }^{2}$ ) I55f.; I. H. Marshall, 'The Synoptic Son of Man Sayings in Recent Discussion', NTS 12

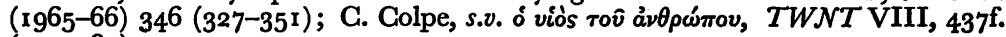
$(403-481)$.

${ }_{22}$ H. Schürmann, op. cit., III, 107, 112. 
I0:26; Lk. I8:42=Mk. I0:52; Lk. 23:35 (bis) =Mk. I 5:3 I (bis); Lk. 23:37=Mk. 15:30-both of these texts are possibly from a non-Marcan source). Twice Luke inserts the verb into Marcan material; it is used of the healing of the demoniac in $8: 36$ (here its use may have been suggested by $M k .5: 23,28$ ), and it is used in 8:12. In this verse we have a connection made between believing and being saved. This connection already exists in Mark 5:34 and 10:52, where the phrase 'your faith has saved you' is used of physical healing. Luke's editing has produced this same connection in 8:50 where Mark merely has 'Only believe'. In two other cases the phrase 'your faith has saved you' occurs in Luke's special material, at the conclusion of the anointing story $(7: 50)$ and of the healing of the ten lepers (I 7:I9). The question now arises whether in these two cases the formula was already in Luke's source or has been added by him as a conventional concluding remark.

In the case of 17:19 the formula is used just as in Mark of physical healing, perhaps with spiritual undertones, but both Klostermann and Bultmann are inclined to regard it as a redactional addition. ${ }^{23}$ This is possible, but it can be argued that the verse is integral to the story by bringing out the fact that only the one leper who returned to Jesus was spiritually healed.

In the case of 7:50 there is no allusion to physical healing, and all the emphasis falls on the forgiveness of sins as the content of salvation. The addition of the words 'Go in peace' is strongly reminiscent of Mark 5:34, and this might suggest that Luke has here made use of Mark. Again, the linking of faith and salvation is found in the language of the early church. We may refer to Acts I $5: 1$ I and I6:3I, and also to Romans I0:9; I Gorinthians I:2 I Ephesians 2:8 and James 2:14. Has Luke projected this language backwards in time onto the lips of Jesus? Once again a hasty conclusion is forbidden by the fact that the link between faith and forgiveness, which is the point of $7: 50$, is already made in Luke 5:20=Mark 2:5.

Three other uses of $\sigma \omega \dot{\zeta} \omega \omega$ in Luke remain to be considered. The sarcastic words of the first malefactor in 23:39 so closely resemble those of the rulers and soldiers in 23:35 and 37 that it may be argued that Luke has put appropriate words into his mouth.

${ }^{23}$ E. Klostermann, op. cit., 174; R. Bultmann, op. cit., 33. 
In Ig:Io we have the statement, 'The Son of man came to seek and save the lost'. Although the saying is regarded as inauthentic by many scholars on account of the use of 'the Son of man' in it, it is unlikely that its formulation should be ascribed to Luke himself. ${ }^{24}$ There are in fact excellent grounds for regarding the saying as going back to Jesus Himself. The whole image of seeking and saving the lost rests on the picture of the shepherd in Ezekiel 34:4, I6, 22, and the metaphor is still alive in the saying. This is not churchly language, but forms part of the pastoral parable material used by Jesus. ${ }^{25}$

In Luke I3:23 Jesus is asked, 'Are the saved few?' The use of oi $\sigma \omega \zeta \zeta^{\prime} \mu \varepsilon v o r$ is reminiscent of early church usage (Acts 2:47; I Cor. 1:18; 2 Cor. 2:15), and therefore the question might be a Lucan formulation to give a setting for the following saying of Jesus. ${ }^{26}$ But the presence of bifror in the parallel passage in Matthew 7:13f. indicates that Luke's question had some basis in the tradition, and the use of $\sigma \omega \zeta \omega$ of future entry to the kingdom of God is attested in Mark ro:26. The formulation may be Lucan, but if so, it is in keeping with the tradition.

There can be no doubt that Luke was fond of the $\sigma \omega \dot{\zeta} \omega$ word group. It is significant that he alone extends the quotation from Isaiah 40:3 found in the other Gospels through to verse 5 to include the words 'and all flesh shall see the salvation of God' (Lk. 3:4-6). The word group also figures prominently in the birth stories (Lk. 1:47, 69, 71, 77; 2:1 I, 30; $f$. Mt. I:2 I). Elsewhere in the Gospel the word owinpi $\alpha$ is found at $19: 9$ in the Zacchaeus story, where there is some possibility that the verse may be a Lucan formulation. ${ }^{27}$

The results of this analysis show that alongside the undoubted addition of $\sigma \omega \zeta \omega$ in Luke 8:12 there are a number of places where Luke may at least be suspected of having added the word group to his sources. Is this to be regarded as a motif which Luke has added to the tradition? This question can be certainly

24 R. Bultmann, op. cit., 33f., apparently ascribes it to Luke. Against him see C. Colpe, op. cit., 456 .

${ }_{25} C f$. A. Oepke, TDNT I, 395; J. Jeremias, TWNT VI, 492; W. Foerster, TWNT VII, 992 ; I. H. Marshall, loc. cit., $342 f$.

${ }^{26}$ For such settings see $11: 27,45 ; 12: 13,41 ; 14: 15 ; 17: 5,20$.

27 The more technical use of $\sigma \omega \tau \eta p l a$ in verse 9 alongside the more metaphorical use of $\sigma \omega \dot{\zeta} \omega \omega$ in verse 10 is perhaps strange. The reference to 'this house' may be thought to be reminiscent of household salvation in Acts, but may be motivated by $19: 5$. 
answered in the negative. For, first of all, the idea of salvation is firmly rooted in the sources. The occurrence of the word $\sigma \omega \zeta \omega$ is undeniable in both Mark and Luke's special source (19:10); its use in the birth stories is also definitely pre-Lucan, particularly in view of the independent occurrence of the same motif in Matthew I:21. Second, the contents of the Gospel as a whole, especially of the L material, illustrate the concept of salvation in its universality. It is impossible to believe that this concept, which permeates the whole extent of the material, is a secondary addition to the material. The conclusion is surely that Luke's concept is one which he inherited as part of the Gospel tradition and not simply as part of the theology of the early church. Thus, to return finally to 8:12 in this connection, Luke has used a vocabulary already attested in his sources to express the meaning of the phrase 'lest they turn and be forgiven'. ${ }^{28}$ Interpretation has taken place, but it is interpretation that is controlled by the sources. ${ }^{29}$

4. The fourth word to occupy our attention is xapdic.30 It occurs twenty-two times in Luke to express the inward source of thought and emotion in men. Luke uses it twice in the present passage, 8:12 and 15 , and the former of these occurrences is paralleled in Matthew I3:19; in the case of Matthew the addition may have been suggested by his earlier use of the word in I 3:I5. The phrase is, however, a perfectly natural periphrasis for Mark's sis aủroús, and may be regarded as a stylistic change. Luke has taken over the same kind of use from Mark (Lk.

${ }^{28}$ This suggestion is made by J. Schmid, Das Evangelium nach Lukas, Verlag Friedrich Pustet, Regensburg (19604) 159; J. Dupont, op. cit., 102, who notes that Luke omits this part of $\mathrm{Mk}$. 4:12 in his rendition of that verse.

${ }_{29}$ According to Dupont Luke wished to tone down the suggestion of predestination in Mk. 4:12 and by his change he managed to indicate that it is not the will of Jesus but of the devil (8:12) that men fail to be converted and saved (cf. Acts $5: 3 ; 13: 8,10)$. This suggestion is not convincing, for Luke has left Mk. 4:12a standing, and has in fact quoted the passage in full at Acts $28: 26 f$. $C f$. W. C. Robinson, op. cit., I 35 , who holds that Luke is distinguishing between the time of Jesus $(8: 9,10)$ and the time of the church $(8: 11-15)$.

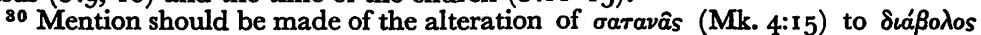

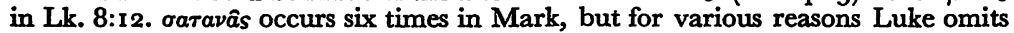
the remaining five of these. It occurs also in Mt. 4:10, but Lk. 4:8 omits the phrase. Luke's use of $\delta t a ́$ ' $\beta$ dos is confined to $4: 2,3,6,13$, where it is taken over from $Q$. Cf. Acts 10:38; 13:10. Luke thus appears to dislike oaravâs rather than to have a

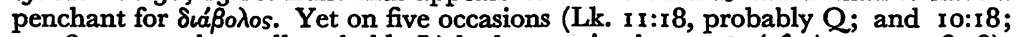
13:16; 22:3 and 31 , all probably $L$ ) he has retained oaravâs (cf. Acts $5: 3 ; 26: 18$ ). The usage is hard to explain. In Acts Luke uses oaravâs in Jewish contexts and

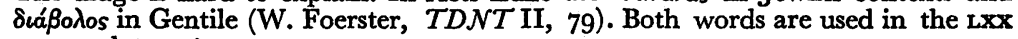
to translate pợ. 
$5: 22=$ Mk. 2:8) and from Q (Lk. 6:45b=Mt. I2:34; Lk. I2:34= Mt. 6:2 I ; Lk. I2:45=Mt. 24:48). Luke I0:27 is dependent on the $\operatorname{Lxx}$ (Dt. 6:5). He has added xapdic at 9:47 (contrast Mk. 9:33f.), thus balancing his omission of the word in his reproduction of Mark 2:6, 8, and he has also added it in Luke $6: 45 \mathrm{a}$ on the analogy of the second part of the verse. He is no doubt himself responsible for the phrase used in 3:I5. J. Dupont suggests that Luke has added the word in 21:14.31 This is possible, especially in view of the occurrence of the same phrase in $1: 66$ and Acts 5:4 (cf. Lk. 9:44; Acts 19:2 I ; and also Lk. 2:19, 5I), whether or not Luke's version of the 'synoptic apocalypse' is dependent on Mark at this point. It seems clear, however, that no theological emphasis is being intended, and therefore we need devote no further attention to the point.

5. Our fifth set of problems arise from certain phrases in verse $13 \mathrm{~b}$. Here in effect Luke substitutes $\pi \varepsilon i p \alpha \sigma \mu o ́ s$ for Mark's

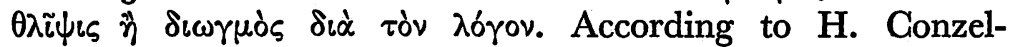
mann the word $\theta \lambda \tilde{i} \psi\llcorner s$ is used by Mark as an eschatological term to refer to a particular stage in the events preceding the parousia (Mk. I3:I9, 24). Luke (he says) avoids the use of the term in his version of the apocalypse because he regards $\theta \lambda \tilde{i} \psi i s$ as the fate of believers rather than of the Jews ( $L k .21: 20-24$ ), and in the present passage Luke has substituted the noneschatological word $\pi \varepsilon i p \alpha \sigma \mu o ́ s$ and emphasized its continual presence. Finally, in Acts Luke does use $\theta \lambda \tilde{\imath} \psi(\varsigma \mathrm{s}$ but uses it of the persecutions which accompany Christians throughout their life. ${ }^{32}$

This interpretation represents a complete travesty of the facts. In the first place, it is a moot point whether the $\theta \lambda \tilde{i} \psi \iota s$ in Mark 13 is directed solely against non-Christian Jews. The whole point of that section is to warn disciples lest they share in the tribulation which is coming. Moreover, if Luke has tried to restrict the application of $\theta \lambda \tilde{i} \psi i s$ to believers, he has not been consistent; see Acts 7:II. And if $\theta \lambda \tilde{\imath} \psi(\mathrm{L} s$ is a danger for believers, why has Luke avoided the word in Luke 8:13? For, second, Conzelmann's argument that $\theta \lambda \tilde{\imath} \psi \mathrm{l} s \mathrm{~s}$ has an eschatological meaning is not true for Mark 4:17. This is shown by the lack of the article with the phrase and the use of

31 J. Dupont, op. cit., 101 n. 12.

32 H. Conzelmann, op. cit., 90. 
the epexegetic phrase 'or persecution', both of which imply a recurring event in the life of believers. We may also use here the fact that in Acts, and indeed throughout the New Testament (except Rev. 7:14) the word $\theta \lambda \tilde{i} \psi \mathrm{L}_{5}$ denotes tribulation in general rather than one specific final 'great tribulation'. All such tribulation is eschatological in the sense that the last days have already begun. ${ }^{33}$ Thirdly, the word $\pi \varepsilon i p \alpha \sigma \mu o ́ s$ is no more or less eschatological than $\theta \lambda i \tilde{\psi} \iota s ;$ see Revelation 3:10.

We can, therefore, confidently reject Conzelmann's interpretation of Luke's alteration here. If we want a more probable explanation, it seems likely that Luke has simply chosen to bring out the character of tribulation and persecution as a means of trying and testing the faith of believers.

H. Schlier refers to how Luke has 'characteristically rendered' this phrase. ${ }^{34}$ Analysis, shows, however, that there is no question of Luke using a characteristic idea here. He uses the noun $\pi \varepsilon i p \alpha \sigma \mu o ́ s$ a further five times in the Gospel and only once in Acts. Luke I I:4 occurs in the Lord's Prayer, and is taken from tradition. Luke 22:46 is parallel to Mark $14: 38$, and 22:40 is simply an anticipation of the later verse. Luke $4: 13$ uses the word entirely naturally in the context of the temptation narrative. Finally, it occurs in 22:28 where it is most probably pre-

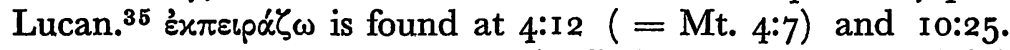

There is no obvious reason why Luke has not worked $\delta i \dot{\alpha}$

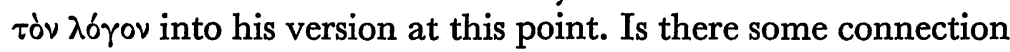
with his avoidance of the phrase 'for the sake of the gospel' (Mk. 8:35; I0:29) ? So far as the use of $\dot{\alpha} \varphi$ i $\sigma \tau \alpha \mu \alpha \iota$ is concerned, Luke has used a favourite word (four times in the Gospel; six times in Acts) to replace $\sigma x \alpha \nu \delta \alpha \lambda i \zeta o \mu \alpha$, a word which he takes over from his sources only twice (Lk. 7:23 = Mt. I I:6; Lk. I 7:If. $=$ Mt. I8:6f.). ${ }^{36}$

6. Sixthly, we consider the changes in the list of temptations in verse 14 . In general Luke has abbreviated them and so sharpened their force. ${ }^{37}$ For 'the cares of the world' he has

\footnotetext{
${ }^{33} \mathrm{H}$. Schlier, TDNT III, I39-148, especially 144-1 4.6; H. Seesemann, TWNT VI, 23-37, especially 31 .

${ }^{34} \mathrm{H}$. Schlier, op. cit., 147.

36 H. Schürmann, op. cit., III, 39 .

${ }^{36} \sigma \kappa a \nu \delta a \lambda i ́ \zeta o p a \iota$ and $\sigma \kappa a ́ \nu \delta a \lambda o \nu$ are uncommon outside Biblical Greek. This may explain Luke's avoidance of them (J. Dupont, op. cit., ro4 n. 23).

${ }^{37}$ J. Dupont, op. cit., 105.
} 


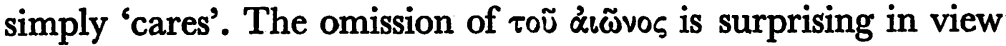
of the use of this phrase in $16: 8$ and 20:34 of 'the sons of this age'. It looks, however, as if Luke has chosen to link all three nouns with the final genitive phrase (so Rsv, Jer. B).$^{38}$ If this is so, we are to think of 'the cares of life'; ßios here will mean life ( $c f$. I Tim. 2:2; 2 Tim. 2:4; I Jn. 2:16; 3:I 7) rather than 'livelihood' (Lk. I5:12, 30; 21:4). If this is the case, a close

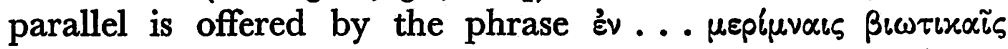
in $21: 34$. This verse comes from a passage which critics almost universally agree to be a late composition in Hellenisticlanguage. In fact, the language is based on Isaiah 24:I 7, $20 \mathrm{Lxx}$, as B. S. Easton observed, ${ }^{39}$ and the Son of man saying which concludes the section has good claims to authenticity. ${ }^{40}$ Consequently, the passage may well be based on early tradition. ${ }^{41}$ However, the phrase in question may represent Lucan editing, or it is possible that this passage has influenced Luke's formulation in 8:14.

For 'the deceitfulness of riches' Luke simply has 'riches'. Again it is surprising that Luke has made a change, for there is an undoubted stress on the danger of riches in his Gospel, and Mark's phrase brings out the danger well. It may be, however, that Luke intends the word í $\delta$ ov' $\dot{\eta}$ which comes third in his list to be partly a substitute for $\alpha \pi \alpha i \eta \eta$. Mark's

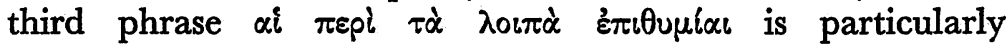
difficult, and has been dropped by Matthew. Luke may well have adopted a phrase which spans both of Mark's second and third items. ${ }^{\mathbf{4 2}}$

Once again, there is nothing of deep theological significance here, but rather an attempt to clarify for the benefit of a new audience. With a certain reserve we may talk about Hellenization being practised by Luke, but such Hellenization does not affect the basic meaning of the section, nor does it suggest that Luke has a preoccupation with the ethical aspects of the Ghristian life. ${ }^{43}$

7. Finally, there are the two characteristics of the believers

38 The omission of the article with all three nouns looks like a case of 'resemitizing'.

${ }^{30}$ B. S. Easton, op. cit., 314 f.

40 C. Colpe, op. cit., 437 .

41 J. Jeremias, The Parables of Fesus, 78 n. 28.

42 For the equivalence of $\dot{\eta} \delta \circ \eta^{\prime}$ and $\dot{\epsilon} \pi \theta v \mu i_{a}$ see Titus $3: 3$.

43 Against H. Conzelmann, op. cit., 21 7-219. 


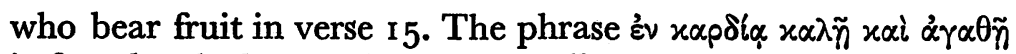
is found only here. This is generally thought to be a certain case of Hellenistic language, for the combination is attested in Greek sources, ${ }^{44}$ but it is doubtful whether Luke has done any more than use a current phrase suggested by the adjectives which describe the soil. It is worth noting that Luke has introduced the adjective $\alpha^{\prime} \gamma \alpha \theta b s$ to describe the soil in the parable itself and uses $x \alpha \lambda 6 \sigma_{s}$ as a synonym in the interpretation. When we note further that the phrase had already penetrated Hellenistic Judaism with no trace of its characteristic Glassical Greek meaning, it seems very doubtful whether we can talk of Hellenistic thought on Luke's part. There is certainly no further development of this motif by Luke.

The other addition peculiar to Luke in this verse is that of

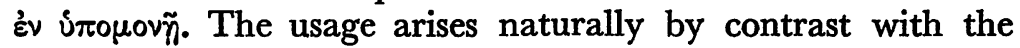
fickleness of the believers who fall away. But the idea is again scarcely Lucan. The word is used only once more in the Gospel, at 2r:19 where it is Luke's equivalent for the use of the verb in Mark 13:13. The thought, however, does come to

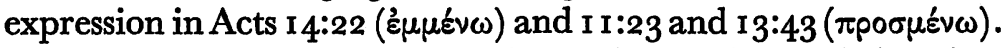
This fact and the use of i $\pi$ orov' in the Epistles (see especially Rom. 5:3) have led to the suggestion that Luke is here influenced by the early church. But in fact Luke's thought is simply an attempt to make more precise what was already in his sources.

It is time to draw together the results of this rather detailed discussion of a comparatively brief text. Our aim was to discover whether any Lucan theological tendency could be found in his treatment of his Marcan material and then to see whether the same tendency could be traced elsewhere in the Gospel. We may sum up the results as follows.

I. The passage which we chose for study has shown that Luke has exercised a fair degree of freedom in reproducing his source. But a very large part of his activity can be understood as a clarification of his source in order to bring out its meaning more clearly for his readers. In doing this Luke has to some extent made use of vocabulary which was current in the early church, but it seems safe to say on the limited basis

${ }^{44}$ W. Grundmann, TDNT I, r If.; III, 538-544, gives the evidence. 
of the present study that Luke has for the most part done no more than bring out a meaning which was already implicit in his source. The notion that Luke has a theological axe to grind and that he rewrites the tradition to support his own distinctive point of view finds remarkably little support in this passage, a passage which was chosen for study because it would appear to have offered considerable scope for such activity.

2. There is no doubt that Luke has to some extent 'Hellenized' the Gospel tradition. ${ }^{45}$ Such activity, however, as we have been able to detect, has shown that the substance of the tradition remains unchanged even though the language has been altered.

3. We may see the distinctive theology of Luke in his references to salvation, a salvation which depends upon believing the Word of God spoken by Jesus and continuing faithfully despite every temptation. This stands out more markedly when we compare Luke's treatment with that of Matthew. Matthew has reproduced Mark's wording much more faithfully than Luke, but he has introduced the idea of understanding into the parable. The evil one snatches away the word from those who hear it but do not understand it; it is the person who hears and understands the words who bears fruit abundantly. This stress on understanding is equally valid, for it is developed from the passage about the mystery of the kingdom and the possibility of hearing without understanding. Nevertheless, as we urged earlier, Luke's theology is one that is based on his sources, and he certainly cannot be accused of altering the basic content of the tradition which he received. Lucan interpretation is there, but it is less in extent than it is often thought to be. ${ }^{46}$

4. Finally, there is the question whether a sound basis for detecting Lucan influence upon his other sources can be gained from observing his use of Mark. The results of our analysis at several points have raised the possibility, some-

45 See the study by W. C. van Unnik, 'Die Motivierung der Feindesliebe in Lukas vi 32-35', NovT 8 (1966) 284-300.

${ }^{46}$ We have not raised the question whether Luke shows signs of a greater accommodation to the so-called delay of the parousia than his predecessors; so far as the passage studied above is concerned, the answer must clearly be in the negative. 
times the probability, that certain forms of wording are Lucan rather than traditional. In several of these cases there is other evidence that may be regarded as confirming our verdict one way or the other. What seems clear is that in the absence of such corrobatory evidence the critic should be very wary of expressing a verdict. Far too much scholarship is based on the weak foundation of unconfirmed hypotheses. The method of seeking for evidence to substantiate novel hypotheses may be slower and less exciting, but there ought to be no doubt that it pays the better dividends in the long run. 